\title{
АНАЛІЗ ПОКАЗНИКІВ НАЙБІЛЬШ РОЗПОВСЮДЖЕНИХ ЗАХВОРЮВАНЬ, ЩО ПЕРЕДАЮТЬСЯ СТАТЕВИМ ШЛЯХОМ, У ВІННИЦЬКІЙ ОБЛАСТІ
}

Вінницький національний медичний університет імені М. І. Пирогова МОЗ України, м. Вінниця, Україна

\begin{abstract}
Мета: проаналізувати динаміку показників найбільш розповсюджених захворювань, що передаються статевим шляхом (ЗПСШ), у Вінницькій області за 2014-2018 рр.

Матеріали і методи. Проведено епідеміологічне ретроспективне дослідження підсумково-звітної статистичної документації Вінницького обласного клінічного шкірно-венерологічного диспансеру (за даними звіту лікувальнопрофрілактичного закладу фр. № 20) з використанням методу викопіювання даних за п'ятирічний період 20142018 рр. Статистичній обробці, аналізу та оцінці підлягали показники найбільш розповсюджених захворювань, що передаються статевим шляхом (сифіліс, гонорея, трихомоніаз, хламідіоз, урогенітальний мікоплазмоз), у Вінницькій області та по Україні. Методи дослідження - епідеміологічний, медико-статистичний.

Результати. Аналіз показників п'яти найбільш розповсюджених захворювань, що передаються статевим шляхом, у Вінницькій області за 2014-2018 рр. виявив, що чотири з них (сифріліс, гонорея, трихомоніаз, хламідіоз) щорічно знижувались, крім урогенітального мікоплазмозу, показник наочності якого у 2018 р. до базового 2014 р. склав (+) 0,9 \%. Така ж тенденція (до зниження), за досліджуваний період, характерна для усіх вказаних захворювань по Україні: сифріліс - (-) 30,2 \%, гонорея - (-) 32,6 \%, трихомоніаз - (-) 31,9 \%, хламідіоз - (-) 16,7 \%, урогенітальний мікоплазмоз - (-) 19,9 \%. Доведено річні темпи зростання регіональних показників виокремлених захворювань за статтю і місцем проживання, крім показника захворюваності на трихомоніаз, який постійно знижувався у всіх когортах.

Висновки. Найбільш вагомими причинами зниження показників розповсюдження захворювань, що передаються статевим шляхом, в Україні й Вінницькій області за досліджуваний період є: 1) відсутність реєстрації цих захворювань y: приватних клініках, переважне звертання хворих до яких пов'язано з причиною уникнення стигматизації, особливо жителів сільської місцевості; фрахівців інших спеціальностей (урологи, акушери-гінекологи та ін.) державних закладів охорони здоров'я; 2) срінансова недоступність до дороговартісної фрармакотерапії.
\end{abstract}

КЛЮчОВІ СЛОВА: захворювання, що передаються статевим шляхом; дерматовенерологічна допомога.

Захворювання (або інфекції), що передаються статевим шляхом (ЗПСШ, або ІПСШ), завдають шкоду сексуальному та репродуктивному здоров'ю населення всього світу і можуть призводити до таких серйозних наслідків, як: мертвонародження, смерть новонародженого, недоношеність, уроджені вади, безпліддя, захворювання на рак шийки матки, запальні захворювання органів малого таза тощо [3-5].

Коефіцієнти захворюваності ЗПСШ залишаються високими в більшості країн світу, незважаючи на діагностичні й терапевтичні досягнення, які можуть швидко допомогти пацієнтам з ІПСШ [5].

За даними ВООЗ [1], щоденно відбувається більше одного мільйона випадків зараження інфекціями, що передаються статевим шляхом, тоді як щорічно має місце 376 млн нових випадків зараження однією із чотирьох ІПСШ - хламідіозом, гонореєю, сифрілісом або трихомоніазом. Важливим фрактом $\epsilon$ те, що більшість ЗПСШ перебігають безсимптомно або лише з незначними симптомами, в результаті чого ІПСШ можуть бути

(c) О. М. Комар, І. В. Підлісна, 2019 не виявленими [1, 2]. У 2016 р. 998 тис. вагітних жінок були інфіковані сифрілісом, що призвело до більш ніж 200 тис. випадків мертвонароджень й загибелі новонародженого [1].

Незважаючи на наявний позитивний міжнародний досвід застосування профрілактичних програм і технологій, ця складова надання медичної допомоги не стала пріоритетним, діючим інструментом зміцнення і збереження репродуктивного здоров'я населення в Україні.

Таким чином, питання профілактики ЗПСШ і застосування ефективних профрілактичних технологій, зокрема в практиці сімейної медицини, залишається актуальним поряд із необхідністю виконання положень та завдань Глобальної стратегії сектору охорони здоров'я з ІПСШ на 20162021 pp. (www.apps.who.int).

Мета роботи: проаналізувати динаміку показників найбільш розповсюджених захворювань, що передаються статевим шляхом, у Вінницькій області за 2014-2018 pр.

Матеріали і методи. Проведено епідеміологічне ретроспективне дослідження підсумковозвітної статистичної документації Вінницького 
обласного клінічного шкірно-венерологічного диспансеру (за даними звіту лікувально-профрілактичного закладу ф. № $20-\mathrm{n}=5$ од.) 3 використанням методу викопіювання даних за п'ятирічний період 2014-2018 рр. Статистичній обробці, аналізу та оцінці підлягали показники найбільш розповсюджених ЗПСШ (сифіліс, гонорея, трихомоніаз, хламідіоз, урогенітальний мікоплазмоз) у Вінницькій області та по Україні (за даними Щорічної доповіді про стан здоров'я населення ... 2014, 2015, 2016, 2017, 2018 рр., www.uiph.kiev.ua). Абсолютні й відносні дані згруповано в ряди динаміки й проведено розрахунки показників темпу росту (ТP) і наочності (ПН). Поглиблений аналіз регіональних показників ЗПСШ передбачав їх оцінку за статтю і місцем проживання.

Методи дослідження: епідеміологічний - для вивчення основних тенденцій поширеності найбільш розповсюджених захворювань, що передаються статевим шляхом, серед дорослого й дитячого населення; медико-статистичний для збору, обробки та аналізу інорормації, отриманої під час дослідження.

Результати дослідження та їх обговорення. Спеціалізовану дерматовенерологічну допомогу населенню Вінницької області надають на базі профрільних кабінетів ЦРЛ, МКЛ (ІІ рівень надання медичної допомоги), обласних закладів, кабінетів та відділень Вінницького обласного клінічного шкірно-венерологічного диспансеру (III рівень надання медичної допомоги). Діяльність служби здійснюють відповідно до вимог чинних директивних документів, регламентуючих організацію, стандарти та нормативи надання дерматовенерологічної допомоги населенню, зокрема: Постановою КМУ від 23.03.1998 р. № 357, наказами МО3 України: від 30.12.1992 р. № 207, від 09.04.1998 р. № 92, від 07.06.2004 р. № 286, від 08.05.2009 р. № 312, директивами Вінницької ОДА, ДОЗ ОДА, локальними протоколами тощо.

Аналізуючи динаміку показників п'яти найбільш розповсюджених захворювань, що передаються статевим шляхом, у Вінницькій області за 2014-2018 рр. слід зазначити, що чотири з них (сифіліс, гонорея, трихомоніаз, хламідіоз) щорічно знижувались, крім урогенітального мікоплазмозу, показник наочності якого у 2018 р. до базового 2014 р. склав (+) 0,9\%.

Така ж тенденція (до зниження), за досліджуваний період, характерна для усіх вказаних захворювань по Україні: сифріліс - 3 8,6 до 6,0 (ПН (-) 30,2 \%), гонорея - 3 14,4 до 9,7 (ПН (-) 32,6 \%), трихомоніаз - з 134,1 до 97,1 (ПН (-) 31,9 \%), хламідіоз - 3 53,9 до 38,0 (ПН (-) 16,7 \%), урогенітальний мікоплазмоз - з 73,8 до 59,1 (ПН (-) 19,9 \%) на 100 тис. населення.

Розподіл регіональних показників захворюваності на сиоріліс за статтю і місцем проживання за період 2014-2018 рр. особливостей не виявив. У всіх виокремлених когортах відбулося зниження показників (на 100 тис. дорослого і 10 тис. дитячого населення): чоловіки - 3 13,8 до 4,8 (ПН (-) 65,2 \%), жінки - 3 7,7 до 2,5 (ПН (-) 67,5 \%), діти 0-17 років - 3 1,3 до 0,04 (ПН (-) 0 \%); сільські й міські жителі - (-) 64,4 \% (3 9,0 до 3,2) й (-) 66,7 \% (з 12,0 до 4,0) відповідно. Незначне зростання показника сифрілісу в 2018 р. до 2017 р. виявлено у чоловіків - 3 4,3 до 4,8 (TP (+) 111,6 \%) і міських жителів - 3 3,3 до 4,0 (TP (+) 121,2 \%) на 100 тис. відповідного населення.

Показники захворюваності на гонорею у Вінницькій області, за досліджуваний період, серед усього населення знизились вдвічі - 3 8,3 до 4,5 (ПН (-) 45,8 \%), у сільських жителів - на (-) 30,4 \% (з 9,2 до 6,4), міських - (-) 64,4 \% (3 7,3 до 2,6 на 100 тис. відповідного населення). Виявлено зростання захворюваності (за темпом росту) серед останніх у 2017 р. $(4,2)$ до 2016 р. $(4,0)$ на (+) 105,0\%, а також у жінок в 2015 р. $(4,5)$ до 2014 р. $(3,9)$ на (+) $115,4 \%$. При цьому показник наочності серед чоловіків склав (-) 54,5 \% (6,1 у 2018 р. до 13,4 у 2014 р.), у жінок - (-) 23,1 \% (3,0 до 3,9 відповідно) на 100 тис. відповідного населення.

Оцінка частоти захворюваності на трихомоніаз протягом п'ятирічного періоду особливостей за когортним розподілом не виявила. Статистичні показники у кожній досліджуваній групі знизились удвічі (ПН): все населення - (-) 49,0 \% (3 133,5 до 68,1 на 100 тис. населення у 2018 р.), тоді як серед дитячого - на (-) 99,6 \% (3 6,7 до 0,03 на 10 тис. дитячого населення).

Значні коливання рівня захворюваності за роками й когортами відзначено щодо хламідіозу. Так, у 2015 р. останній зріс у чотирьох досліджуваних групах (ТР): все населення - (+) 246,3% (з 8,5 до 20,2 на 100 тис. населення), у сільських і міських жителів - по (+) 108,0%; у жінок - (+) 121,0 \%. У 2016 р. показник збільшився лише у чоловічій когорті на (+) 120,0 \% (3 3,0 до 3,6), а в 2018 р. серед усього населення, у міських жителів і жінок - на (+) 113,0 \% (3 4,6 до 5,2), (+) 134,0 \% (3 5,3 до 7,1$)$ й (+) 127,4 \% (3 6,2 до 7,9) відповідно. При цьому показник наочності у 2018 р. до базового 2014 р. був від'ємний: все населення - (-) 38,8 \%, сільське - (-) 57,3 \%, міське - (-) 25,3 \%; чоловіча і жіноча стать - (-) 52,4 \% й (-) 34,7 \% відповідно.

Аналіз епідситуації розповсюдження урогенітального мікоплазмому у Вінницькій області в 2014-2018 рр. виявив зростання показника кожних два роки $з$ позитивним ПН у групах (табл. 1): все населення - (+) 0,9 \% (3 11,4 до 11,5), міське (+) 6,3\% (3 19,0 до 20,2), жіноче - (+) 9,1\% (3 18,6 до 20,3 на 100 тис. відповідного населення).

3'ясовано, що у 2015 р. показник захворюваності на урогенітальний мікоплазмоз зріс у всіх досліджуваних групах, крім дитячого населення 
Таблиця 1. Частота розповсюдженості захворювань на урогенітальний мікоплазмоз у Вінницькій області за 2014-2018 рр. (на 100 тис. відповідного населення)

\begin{tabular}{|l|c|c|c|c|c|c|}
\hline \multirow{2}{*}{ Когорти } & \multicolumn{7}{|c|}{ Роки (на 100 тис. відповідного населення) } \\
\cline { 2 - 7 } & 2014 & 2015 & 2016 & 2017 & 2018 & ПН $(+/-)$ \\
\hline Все населення & 11,4 & 12,4 & 11,4 & 12,0 & 11,5 & $+0,9$ \\
\hline Сільське & 3,8 & 5,8 & 5,4 & 5,4 & 2,6 & $-31,6$ \\
\hline Міське & 19,0 & 19,9 & 17,2 & 18,5 & 20,2 & $+6,3$ \\
\hline Чоловіки & 2,9 & 3,8 & 1,9 & 1,2 & 1,2 & $-58,6$ \\
\hline Жінки & 18,6 & 19,8 & 19,5 & 21,3 & 20,3 & $+9,1$ \\
\hline Дитяче (на 10 тис. населення) & 0,07 & 0,07 & 0,07 & 0 & 0 & 0 \\
\hline
\end{tabular}

Примітка. * - показник наочності (дані 2018 р. до базового 2014 р.)

(ТР): все населення - (+) 108,8 \%, сільське - (+) $152,6 \%$, міське - (+) 104,7\%; чоловіче й жіноче (+) 131,0 \% і (+) 106,5 \% відповідно. Щорічне зростання останнього спостерігали серед жителів міст Вінницької області, крім 2016 р.

Підсумовуючи, на перший погляд, можна було б оцінити діяльність дерматовенерологічної служби як регіональної, так і національної. Позитивною є реформа медичної галузі з 2011 р. первинної ланки надання медичної допомоги, яка призвела до зниження розповсюдження ЗПСШ, що є одним із показників якості надання дерматовенерологічної допомоги.

Але, здійснивши поглиблений аналіз причин виявленої тенденції, доведено, що пацієнти надають перевагу анонімному обстеженню і лікуванню у приватних клініках, особливо жителі сільської місцевості (за причини уникнення стигматизації). І системною проблемою на сьогодні залишається відсутність реєстрації випадків ЗПСШ приватними клініками і кабінетами й передача такої звітності (інформації) в центральні органи статистики України. Поряд із цим реєстраційні дані втрачаються при виявленні цих захворювань іншими фрахівцями державних закладів охорони здоров'я (урологами, акушер-гінекологами та ін.).

Ще однією вагомою причиною є фрінансова недоступність значної частки населення до фрармацевтичних препаратів для проведення дороговартісної фрармакотерапії лікувальної (хворим) і профрілактичної (контактним особам). Відзначено, що виявлення й епіднагляд за останніми здійснюють лише спеціалізовані державні заклади охорони здоров'я II і III рівнів надання медичної допомоги, що значно впливає на раннє розпізнавання хвороб та їх розповсюдження.

\section{Висновки}

1. Виявлено національну і регіональну (Вінницька область) тенденцію до зниження показників найбільш розповсюджених захворювань, що передаються статевим шляхом, у 2014-2018 рр. (сиоріліс, гонорея, трихомоніаз, хламідіоз), крім регіонального рівня захворюваності на урогенітальний мікоплазмоз, показник наочності якого у 2018 р. до базового 2014 р. склав (+) 0,9\%.

2. Доведено річні темпи зростання регіональних показників виокремлених ЗПСШ за статтю і місцем проживання, крім показника захворюваності на трихомоніаз, який постійно знижувався у всіх когортах.

3. З'ясовано, що найбільш вагомими причинами виявленої ситуації щодо розповсюдження ЗПСШ в Україні й Вінницькій області є: 1) відсутність реєстрації цих захворювань у: приватних клініках, переважне звертання хворих до яких пов'язано з причиною уникнення стигматизації, особливо жителів сільської місцевості; фрахівців інших спеціальностей (урологи, акушери-гінекологи та ін.) державних закладів охорони здоров'я без передачі інформаційно-звітних даних у центральні органи статистики; 2) фрінансова недоступність до дороговартісної фармакотерапії.

Перспективи подальших досліджень. Одним із завдань подальшого епідеміологічного дослідження $є$ вивчення інфрормованості населення (за різними прицільними когортами) щодо профрілактики та розповсюдження ЗПСШ з урахуванням їх кофракторної дії на передавання ВІЛ-інфрекції.

\section{Список літератури}

1. Инфекции передаваемые половым путем [Электронный ресурс]. - 2019. - ВО3. - Режим доступа : http://www.who. int. - Название с экрана.

2. Инсрекции, передаваемые половым путём и иные инсекции репродуктивного тракта. Руководство по основам медицинской практики [Электронный ресурс]. - 2004. - ВОЗ. - 196 с. - Режим доступа : http://www.euro.who.int. Название с экрана.

3. Калюжная Л. Д. Инфекции, передающиеся половым путём: клиническая картина, диагностика, подходы к лечению [Электронный ресурс] / Л. Д. Калюжная // Украинский медицинский журнал. - № 5 (91). - 2012. - Режим доступа : http://www.umj.com.ua. - Название с экрана. 
4. Кузнецова О. С. Иноекции, передающиеся половым путём, как медико-социальная проблема (по данным литературы) / О. С. Кузнецова, А. В. Чернышев // Вестник ТГУ. - 2014. - Т. 19, № 3. - С. 1009-1011.

5. 5. Sheldon R. Morris. Overview of sexual transmitted diseases [Electronic resource] / Morris R. Sheldon. - USA. - 2018. - Access mode : http://www.msdmanuals.com - Title from the screen.

\section{References}

1. (2019). Infektsii, peredavayemyye polovym putom [Sexually transmitted infections]. VOZ - WHO. Retrieved from: http:// www.who.int [in Russian].

2. (2004). Infektsii, peredavayemyye polovym putom i inyye infektsii reproduktivnogo trakta. Rukovodstvo po osnovam meditsinskoy praktiki [Sexually transmitted infections and other infections of the reproductive tract. Guide to the basics of medical practice]. VOZ - WHO. Retrieved from: http://www.euro.who.int [in Russian].

3. Kalyuzhnaya, L.D. (2012). Infektsii, peredayushchiyesya polovym putom: klinicheskaya kartina, diagnostika, podkhody k lecheniyu [Sexually transmitted infections: clinical picture, diagnosis, treatment approaches]. Ukrainskiy meditsinskiy zhurnal - Ukrainian Medical Journal, 5 (91). Retrieved from: http://www.umj.com.ua [in Ukrainian].

4. Kuznetsova, O.S., \& Chernyshev, A.V. (2014). Infektsii, peredayushchiyesya polovym putom, kak mediko-sotsialnaya problema (po dannym literatury) [Sexually transmitted infections as a medical and social problem (according to literature)]. Vestnik TGU - Bulletin of TSU, 19 (3), 1009-1011 [in Russian].

5. Sheldon, R. Morris. (2018). Overview of sexual transmitted diseases. Retrieved from: http://www.msdmanuals.com

\section{АНАЛИЗ ПОКАЗАТЕЛЕЙ НАИБОЛЕЕ РАСПРОСТРАНЕННЫХ ЗАБОЛЕВАНИЙ, ПЕРЕДАВАЕМЫХ ПОЛОВЫМ ПУТЕМ, В ВИННИЦКОЙ ОБЛАСТИ}

Е. Н. Комар, И. В. Подлесная

Винницкий национальный медицинский университет имени Н. И. Пирогова МЗ Украины, г. Винница, Украина

Цель: проанализировать динамику показателей наиболее распространенных заболеваний, передающихся половым путем (ЗППП), в Винницкой области за 2014-2018 гг.

Материалы и методы. Проведено эпидемиологическое ретроспективное исследование итоговоотчетной статистической документации Винницкого областного клинического кожно-венерологического диспансера (по данным отчета лечебно-профилактического учреждения фр. № 20) с использованием метода выкопировки данных за пятилетний период 2014-2018 гг. Статистической обработке, анализу и оценке подлежали показатели наиболее распространенных ЗППП (сифилис, гонорея, трихомониаз, хламидиоз, урогенитальный микоплазмоз), в Винницкой области и по Украине. Методы исследования эпидемиологический, медико-статистический.

Результаты. Анализ показателей пяти наиболее распространенных заболеваний, передающихся половым путем, в Винницкой области за 2014-2018 гг. обнаружил, что четыре из них (сифилис, гонорея, трихомониаз, хламидиоз) ежегодно снижались, кроме урогенитального микоплазмоза, показатель наглядности которого в 2018 г. до базового 2014 г. составил (+) 0,9\%. Такая же тенденция (к снижению), за исследуемый период, характерная для всех указанных заболеваний по Украине: сифилис - (-) 30,2 \%, гонорея - (-) 32,6 \%, трихомониаз - (-) 31,9 \%, хламидиоз - (-) 16,7 \%, урогенитальный микоплазмоз (-) 19,9 \%. Доказано годовые темпы увеличения региональных показателей выделенных заболеваний по полу и месту жительства, кроме показателя заболеваемости трихомониазом, который постоянно снижался во всех когортах.

Выводы. Наиболее весомыми причинами снижения показателей распространения заболеваний, передающихся половым путем, в Украине и Винницкой области за исследуемый период являются: 1) отсутствие регистрации этих заболеваний в: частных клиниках, преимущественное обращение больных к которым связано с причиной избежания стигматизации, особенно жителей сельской местности; специалистов других специальностей (урологи, акушеры-гинекологи и др.) государственных учреждений здравоохранения; 2) фринансовая недоступность к дорогостоящей фрармакотерапии.

КЛЮЧЕВЫЕ СЛОВА: заболевания, передающиеся половым путем; дерматовенерологическая помощь.

\section{ANALYSIS OF THE INDICATORS OF THE MOST WIDESPREAD SEXUALLY TRANSMITTED DISEASES IN VINNYTSIA REGION}

O. M. Komar, I. V. Pidlisna

M. Pyrohov Vinnytsia National Medical University, Vinnytsia, Ukraine

Purpose: to analyze the dynamics of the most widespread sexually transmitted diseases (STDs) indicators in Vinnytsia region within 2014-2018.

Materials and Methods. An epidemiological retrospective research of the summary and statistical documentation of the Vinnytsia Regional Clinical Dermatovenerologic Dispensary (according to the Report of the Therapeutic and Prophylactic Institution No. 20) was carried out using the data retrieval method for the five-year 
period starting from 2014 to 2018. The parameters of the most common STDs in the Vinnytsia region and Ukraine (syphilis, gonorrhea, trichomoniasis, chlamidiosis, urogenital mycoplasmosis) were treated with the means of statistical processing, analysis and evaluation. Methods of research - epidemiological, medical and statistical.

Results. The analysis of the five most common STDs indicators in the Vinnytsia region throughout 2014-2018 showed that four of them (syphilis, gonorrhea, trichomoniasis, chlamidiosis) have been decreasing annually, except for urogenital mycoplasmosis, whose visibility in 2018 in comparison with 2014 base was (+) $0.9 \%$. The same trend (to decrease) for the period researched is typical for all of the mentioned diseases in Ukraine: syphilis (-) $30.2 \%$, gonorrhea - (-) $32.6 \%$, trichomoniasis - (-) $31.9 \%$, chlamidiosis - (-) $16.7 \%$, urogenital mycoplasmosis - (-) $19.9 \%$. The annual growth (according to the growth rate) of the regional indicators of specific diseases by gender and place of residence is proven but the incidence rate of trichomoniasis, which was constantly decreasing in all cohorts.

Conclusions. The most important reasons for the decrease in the incidence of STDs in Ukraine and in the Vinnytsia region for the period researched are the following: 1) the absence of registration of these diseases in: private clinics, the predominant treatment of patients is due to the avoidance of stigmatization, especially among the people of rural areas; specialists of other specialties (urologists, obstetrician-gynecologists, etc.) of public health institutions; 2) financial inaccessibility to expensive medicines.

Key words: sexually transmitted diseases; dermato-venereal aid.

Рукопис надійшов до редакції 09.07.2019 р.

\author{
Відомості про авторів: \\ Комар Олена Миколаївна - доктор медичних наук, професор кафедри соціальної медицини та організації \\ охорони здоров'я Вінницького національного медичного університету імені М. І. Пирогова МОЗ України; \\ тел.: +38(097) 482-48-25.
}

Підлісна Ірина Володимирівна - аспірант кафедри соціальної медицини та організації охорони здоров'я Вінницького національного медичного університету імені М. І. Пирогова МОЗ України; тел.: +38(097) 441-40-41. 